\title{
Rancang Bangun Alat Screw Extruder Pada Pembuatan Papan Partikel Berbahan Dasar Tandan Kosong Kelapa Sawit Dan Plastik Polypropylene (PP)
}

\author{
Amalia Adriatna Putri ${ }^{* 1}$, Anerasari², Indah Purnamasari ${ }^{3}$ \\ ${ }^{1,2,3}$ Program Studi Teknologi Kimia Industri, Jurusan Teknik Kimia, \\ Politeknik Negeri Sriwijaya, Indonesia. \\ Email: ${ }^{1}$ amaliaadriatnaputri@gmail.com
}

\begin{abstract}
Abstrak
Peningkatan limbah plastik dan Tanda Kosong Kelapa Sawit (TKKS) yang sangat besar di Indonesia dikhawatirkan akan memberikan dampak buruk bagi lingkungan. Papan partikel dapat dibuat dari limbah plastik Polypropylene yang digunakan sebagai perekat dan bahan isiannya berupa dari Tandan Kosong Kelapa Sawit (TKKS) dengan menggunakan alat Screw Extruder dengan memvariasikan kecepatan putaran Screw. Untuk melihat kinerja dari Screw Extruder yang dirancang, perbandingan komposisi Tandan Kosong Kelapa Sawit (TKKS) dan perekat Polypropylene (45:55, 40:60, 35:75, 30:70, 25:75). Sehingga didapatkan papan partikel yang telah memenuhi SNI 03-2105- 2006 dengan kondisi optimum untuk nilai kerapatan tertinggi yaitu pada kecepatan putaran screw $60 \mathrm{rpm}$ dengan perbandingan komposisi bahan 25:75, untuk nilai kadar air, daya serap, dan pengembangan tebal yaitu pada kecepatan putaran screw $20 \mathrm{rpm}$ dengan perbandingan komposisi bahan 45:55
\end{abstract}

Kata kunci: papan partikel, polypropylene, screw extruder, tandan kosong kelapa sawit.

\section{The Design of A Screw Extruder on The Making of Particle Board Made from An Empty Bunches of Oil Palm and Polypropylene Plastic (PP)}

\begin{abstract}
A huge increase of plastic waste and Empty Palm Oil mark in Indonesia are feared to have an adverse impact for the environment. Particle boards can be made of Polypropylene plastic waste which is used as an adhesive and the filling material is form the Empty Palm Bunches using a Screw Extruder tool by varying the screw rotation speed. To see the performance of the designed Screw Extruder, comparison between of the composition of Empty Palm Bunches and Polypropylene adhesive is 45:55, 40:60, 35:75, 30:70, 25:7). So that the board has met SNI 03-2105-2006 with optimum conditions for the highest density value, namely the screw rotation speed of $60 \mathrm{rpm}$ with a material composition ratio of 25:75, for the value of absorption water content, and the development of screw thick is at screw speed rotation of 20 rpm with a material ratio of 45:5.
\end{abstract}

Keywords: empty palm oil, particle board, polypropylene.

\section{PENDAHULUAN}

Pertumbuhan manusia di Indonesia tiap tahunnya mengalami peningkatan, begitu juga dengan kebutuhan bahan baku kayu di lingkungan masyarakat sebagai bahan bangunan ataupun penunjang industri. Adapun produktivitas kayu sebagai bahan baku mengalami penurunan diakibatkan oleh jumlah kayu yang tersedia di hutan semakin sedikit dan ketidakseimbangan antara pemanenan kayu dan rentang tanah. Untuk mengatasi permasalahan tersebut perlu dilakukannya kegiatan alternatif dengan melakukan metodologi pengolahan kayu dari bahan baku yang mengandung lignoselulosa untuk mengurangi penggunaan kayu secara total.[1]

Papan partikel merupakan salah satu jenis produk panel kayu atau komposit yang terbuat dari partikelpartikel kayu atau bahan mengandung lignoselulosa lainnya, yang diikat dengan perekat sintetis atau bahan pengikat lain dan dikempa dengan panas[2]. Dalam pembuatan papan partikel salah satu faktor yang berperan penting ialah proses perekatan, dimana tipe dan sifat dari papan partikel yang dihasilkan ditentukan oleh komposisi dan jenis perekat yang digunakan.

Berdasarkan penelitian yang telah dilakukan oleh peneliti terdahulu mengenai sifat fisik dan mekanis dari komposit kayu dan limbah plastik Polypropylene (PP) dengan variabel ukuran butiran pengisi ataupun matriks dengan penambahan stabilyzer MAH sebesar 2,5\%. Hasil dari penelitian ini menunjukkan 
bahwa semakin kecil ukuran partikel pengisi maka sifat mekanis maupun sifat fisik komposit akan meningkat. Hasil paling optimum dicapai oleh komposit dengan perbandingan serbuk kayu dan matriks PP sebesar 50:50[3].

Extruder memiliki fungsi sebagai pelebur plastik yang nantinya akan diproses melalui zona pemanas yang memiliki suhu berbeda-beda dan akan didorong keluar oleh screw conveyor untuk sampai pada bagian die untuk berbagai macam proses selanjutnya[4]. Die berfungsi sebagai pembentuk dan pencetak bahan setelah diolah di dalam extruder ke bentuk yang diinginkan. Keunggulan proses ini adalah proses dapat dilakukan secara kontinyu sehingga secara langsung dapat dilakukan proses pencetakan.

Prinsip kerja dari alat Screw Extruder yaitu bahan diisikan melalui corong ke dalam laras/tabung berulir secara berkesinambungan. Putaran ulir menyebabkan bahan terdorong ke bagian die. Selama proses ini, bahan mengalami gaya tekan dan gesekan antara ulir dengan bahan. Gesekan yang dialami oleh bahan turut serta menimbulkan kalor yang memanaskan bahan tersebut. Bahan yang keluar selanjutnya masuk kedalam cetakan yang telah dipasang pada ujung die. Bahan yang telah keluar dari ekstruder mengalami perubahan tekanan dan suhu yang jauh lebih rendah daripada di dalam ekstruder. Pada kondisi tersebut air di dalam bahan, sebelumnya dalam keadaan bersuhu tinggi $\left(150-200^{\circ} \mathrm{C}\right)$ di dalam ekstruder, akan mudah menguap ke udara. Hal ini menyebabkan terciptanya rongga - rongga udara di dalam bahan sekaligus tertariknya molekul bahan. Kondisi ini menyebabkan proses pengembangan bahan.

Penelitian rancang bangun pembuatan alat papan serat dengan metode Screw Exturder mengacu pada penelitian Satito [5] tentang pembuatan papan partikel dengan alat Screw Extruder berkapasitas $50 \mathrm{~kg} / \mathrm{jam}$ menghasilkan papan kayu berkualitas baik, Alat tersebut juga masih menggunakan unit penggerak transmisi pulley dan belt. Dilakukan penelitan rancang bangun alat Screw Extruder dengan memodifikasi insulasi pada barrel dan penggunaan Inverter yang seringkali disebut Variable Speed Drive (VSD) pada motor penggerak. Penggunaan VSD pada motor listrik dapat menyesuaikan kecepatan screw sesuai dengan yang dibutuhkan dalam proses ekstrusi sehingga mencegah terjadinya penggunaan energi yang sia-sia dan mampu mengurangi biaya listrik.

\section{METODE PENELITIAN}

\subsection{Waktu dan Tempat}

Pelaksanaan pembuatan alat dilakukan pada bulan April-Juni 2021, sementara penelitian dilakukan pada bulan Juni-Juli 2021 di Laboratorium Satuan Operasi dan Pilot Plant Jurusan Teknik Kimia Politeknik Negeri Sriwijaya.

\subsection{Alat dan Bahan}

Adapun alat yang digunakan dalam rancang bangun alat yaitu mesin las, gerinda, bor, obeng, tang, palu, kunci inggris, penggaris siku, meteran, kuas, pensil, gunting, solder. Sedangkan alat yang digunakan untuk penelitian yaitu gelas kimia, gelas ukur, neraca analitik, wadah plastik, lap kain, stopwatch.

Bahan yang digunakan dalam rancang bangun alat rangka (besi hollow), barrel, screw, Variable Speed Drive (VSD), tachometer digital, hopper, band heater, motor induksi 2hp, gearbox transmisi, Mechanical Adjustable Speed Drive (Rantai dan Gear), diehead, cetakan, plat alumunium, bearing set, control panel, sensor termokopel, kabel, saklar on/off, potensio, papan tripleks, baut 12 dan 14, sekrup, cat, thinner, amplas, lem kabel, dan timah. Sedangkan bahan yang digunakan pada penelitian yaitu tandan kosong kelapa sawit, plastik polypropylene, natrium hidroksida, aquadest.

\subsection{Persiapan Bahan}

Bahan yang digunakan untuk membuat papan partikel pada penelitian ini adalah tandan kosong kelapa sawit dan plastik Polypropylene (PP). Tandan kosong kelapa sawit yang akan diolah diambil, dipotong- potong hingga berukuran $10 \mathrm{~cm}$, dicuci bersih dan ditiriskan lalu dijemur dibawah sinar matahari hingga kadar air $<5 \%$. Perlakuan alkalisasi pada tandan kosong kelapa sawit dengan direndam larutan $\mathrm{NaOH} 6 \%$ selama 60 menit. Kemudian dibilas dengan air hingga $\mathrm{pH}$ 7-7,5. Tandan kosong kelapa sawit dikeringkan dengan oven pada temperature $170^{\circ} \mathrm{C}$ hingga berat konstan. Setelah dikeringkan. Selanjutnya Tandan Kosong Kelapa Sawit dihaluskan hingga berukuran 10 mesh. Plastik Polypropylene (PP) disortir, dicuci hingga bersih dan ditiriskan lalu dikeringkan dan dipotong-potong hingga berukuran 1-2 $\mathrm{cm}$.

\subsection{Tahap Peleburan}

Memanaskan alat Screw Extruder hingga suhu $250^{\circ} \mathrm{C}$. Partikel Tandan Kelapa Sawit Kosong (TKKS) dan 
Plastik Polypropylene (PP) yang telah dicampur rata, dimasukkan kedalam alat Screw Extruder dengan komposisi yang telah ditentukan

\subsection{Tahap Percetakan}

Campuran partikel tandan kelapa sawit dan plastik yang telah homogen dikeluarkan dari Screw Extruder melalui katup dan dimasukkan kedalam cetakan besi. Pastikan campuran tersebut telah benar-benar padat dan tersebar secara merata didalam cetakan agar menghasilkan papan partikel dengan kerapatan yang seragam.

\subsection{Tahap Analisis}

Tahap analisis bertujuan untuk mengetahui kualitas papan partikel. Analisis yang dilakukan pada percobaan ini meliputi: Analisis kadar air, analisis kerapatan, analisis daya serap, dan analisis pengembangan tebal.

\section{HASIL DAN PEMBAHASAN}

Perancangan alat Screw Extruder dalam pembuatan Papan Partikel berbahan dasar tandan kosong kelapa sawit dan perekat plastik Polyrpopyelene sehingga menghasilkan Papan Partikel yang memenuhi SNI 03-21052006.

\subsection{Kadar Air}

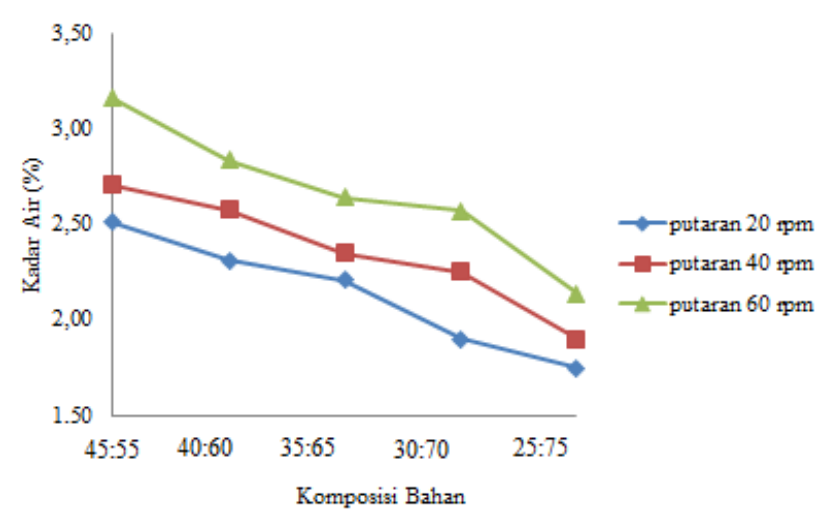

Gambar 1. Pengaruh Perbandingan Komposisi Bahan dan Kecepatan Putaran Screw terhadap Kadar Air pada Papan Partikel

Peningkatan jumlah perekat pada pembuatan papan partikel sangat berpengaruh terhadap nilai kadar airnya. Pada Gambar 1. yang dapat dilihat bahwa papan partikel dengan perbandingan komposisi bahan yaitu 45:55 dengan kecepatan putaran screw $60 \mathrm{rpm}$ sedangkan untuk kadar air dengan nilai rendah pada papan partikel dengan perbandingan komposisi bahan yaitu 25:75 dengan kecepatan putaran screw $20 \mathrm{rpm}$. Hal tersebut disebabkan karena putaran yang lebih cepat menyebabkan TKKS dan perekat plastik Polypropylene (PP) tidak terhomogenisasi dengan baik. Berdasarkan Gambar 1. juga dapat dilihat bahwa semakin banyaknya persentase serat TKKS dan sedikit persentase perekat plastik Polypropylene (PP), maka akan mempengaruhi banyaknya kadar air yang terkandung pada papan partikel. Sehingga nilai kadar air yang terkandung dalam papan partikel semakin tinggi yang akan menyebabkan ikatan rekat menjadi lemah. Hal ini disebabkan karena banyaknya rongga pada papan partikel yang tidak tertutupi oleh perekat plastik Polypropylene (PP) sehingga kurangnya kemampuan dalam menyerap air dari udara

\subsection{Kerapatan}

Kecepatan putaran screw sangat berpengaruh pada nilai kerapatan, dimana semakin lama putaran screw maka campuran antara TKKS dan Perekat Plastik Polypropylene (PP) terhomogenisasi dengan baik sehingga mudah untuk mengisi ruang dicetakan dan tidak terciptanya rongga-rongga pada papan partikel karena telah diisi oleh perekat plastik Polypropylene (PP). Pada Gambar 2. dapat dilihat bahwa papan partikel yang memiliki nilai kerapatan yang tertinggi yaitu pada papan partikel dengan perbandingan komposisi 25:75 dengan kecepatan putaran screw $20 \mathrm{rpm}$. Sedangkan untuk nilai kerapatan terendah yaitu pada papan partikel dengan perbandingan komposisi bahan dengan perbandingan 45:55 dengan kecepatan putaran screw $60 \mathrm{rpm}$. Dimana semakin bertambahnya komposisi perekat maka nilai kerapatan pada papan partikel semakin meningkat. Hal tersebut sesuai dengan pernyataan Penambahan persentase perekat pada papan partikel akan menambah massa bahan 
baku sehingga nilai kerapatan yang diperoleh semakin tinggi. Mawardi [6] menyatakan bahwa kerapatan papan partikel memiliki pengaruh besar terhadap pengembangan tebal dan daya serap air pada papan partikel. Rendahnya nilai kerapatan menyebabkan tingginya nilai pengembangan tebal dan daya serap air papan.

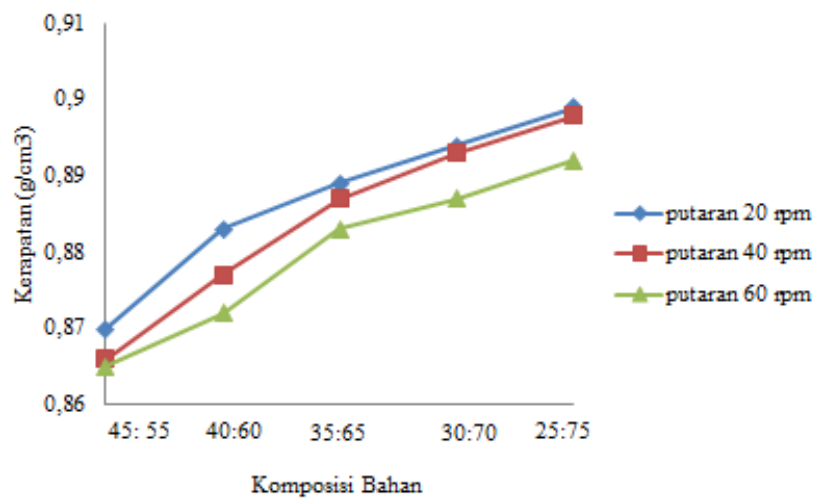

Gambar 2. Pengaruh Perbandingan Komposisi Bahan dan Kecepatan Putaran Screw terhadap Kerapatan pada Papan Partikel

\subsection{Daya Serap}

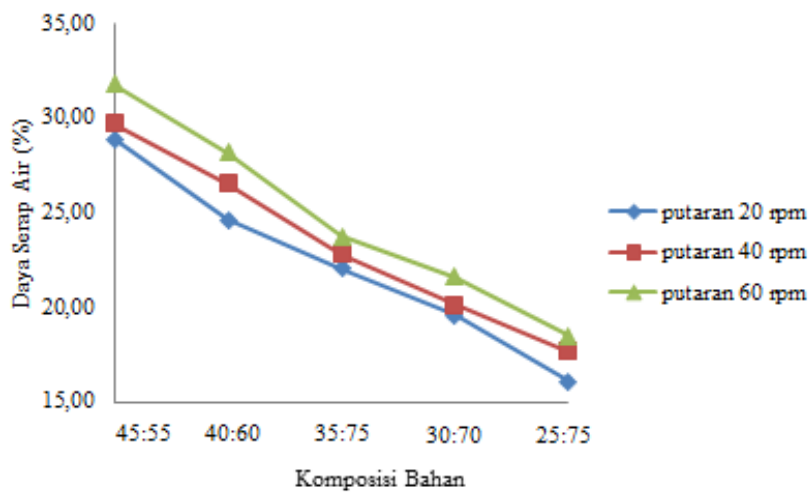

Gambar 3. Pengaruh Perbandingan Komposisi Bahan dan Kecepatan Putaran Screw terhadap Daya Serap pada Papan Partikel

Kecepatan putaran screw sangat berpengaruh pada nilai kerapatan, dimana semakin lama putaran screw maka campuran antara TKKS dan Perekat Plastik Polypropylene (PP) terhomogenisasi dengan baik sehingga mudah untuk mengisi ruang dicetakan dan tidak terciptanya rongga-rongga pada papan partikel karena telah diisi oleh perekat plastik Polypropylene (PP). Pada Gambar 2. dapat dilihat bahwa papan partikel yang memiliki nilai kerapatan yang tertinggi yaitu pada papan partikel dengan perbandingan komposisi 25:75 dengan kecepatan putaran screw $20 \mathrm{rpm}$. Sedangkan untuk nilai kerapatan terendah yaitu pada papan partikel dengan perbandingan komposisi bahan dengan perbandingan 45:55 dengan kecepatan putaran screw $60 \mathrm{rpm}$. Dimana semakin bertambahnya komposisi perekat maka nilai kerapatan pada papan partikel semakin meningkat. Hal tersebut sesuai dengan pernyataan Mawardi [6] yang menyatakan bahwa, semakin tinggi persentase perekat yang digunakan, maka semakin tinggi sifat fisis dan mekanik pada papan partikel. Penambahan persentase perekat pada papan partikel akan menambah massa bahan baku sehingga nilai kerapatan yang diperoleh semakin tinggi. Mawardi [6] juga menyatakan bahwa kerapatan papan partikel memiliki pengaruh besar terhadap pengembangan tebal dan daya serap air pada papan partikel. Rendahnya nilai kerapatan menyebabkan tingginya nilai pengembangan tebal dan daya serap air papan. Mawardi [6] juga menyatakan bahwa kerapatan papan partikel memiliki pengaruh besar terhadap pengembangan tebal dan daya serap air pada papan partikel. Rendahnya nilai kerapatan menyebabkan tingginya nilai pengembangan tebal dan daya serap air papan

\subsection{Pengembangan Tebal}

Pada Gambar 4. dapat dilihat bahwa untuk pengembangan tebal pada papan partikel tertinggi yaitu pada perbandingan komposisi bahan yaitu 45:55 dengan kecepatan putaran screw $60 \mathrm{rpm}$. Sedangkan untuk pengembangan tebal pada papan partikel terendah yaitu pada perbandingan komposisi bahan 25:75 dengan 
kecepatan putaran screw $20 \mathrm{rpm}$. Berdasarkan Mawardi [6] menjelaskan bahwa Pertambahan pengembangan tebal seiring dengan pertambahan daya serap air papan serat. Serat semakin terlapisi dengan baik oleh perekat sehingga kontak antara serat dan air menjadi lebih kecil. Perekat yang memasuki dinding serat dan kemudian mengeras dapat menciptakan hambatan fisik (physical barrier) sehingga menyebabkan penurunan penyerapan air yang menyebabkan pengembangan tebal. Menurut Hesty [7] sifat pengembangan tebal papan serat sejalan dengan sifat daya serap air, yaitu semakin banyak air yang diserap makin besar pengembangan tebalnya. Kecepatan putaran screw juga berpengaruh terhadap nilai pengembangan tebal pada papan partikel. Dimana semakin cepat kecepatan putaran screw maka sulitnya campuran TKKS dan Plastik Polypropylene untuk mengisi ruang didalam cetakan, sehingga makin kecil nilai pengembangan tebal papan partikel. Keadaan ini disebabkan pada waktu perendaman serat TKKS akan menarik air kembali sehingga serat-serat papan partikel akan kembali menjadi bentuk semula akibat hilangnya tekanan setelah perendamanDipersilakan untuk menambah bab sesuai dengan kebutuhan.

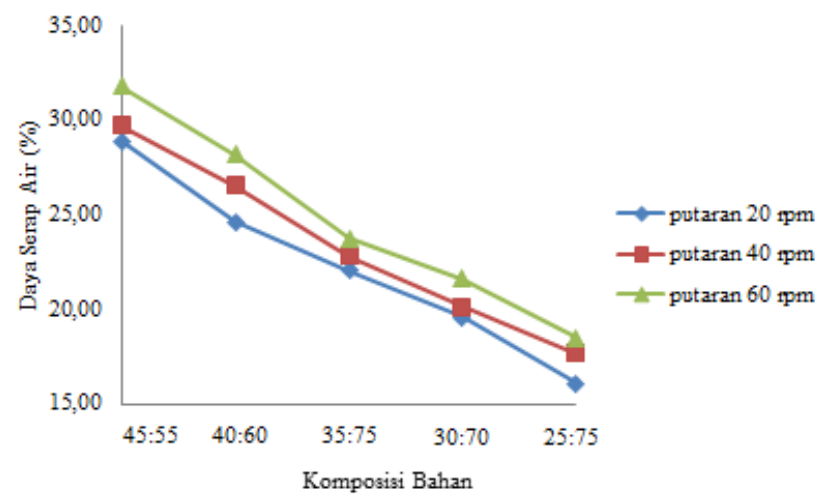

Gambar 4. Grafik Pengaruh Perbandingan Komposisi Bahan dan Kecepatan Putaran Screw terhadap Pengembangan Tebal pada Papan Partikel

\section{KESIMPULAN}

Berdasarkan hasil penelitian yang telah dilakukan, maka didapatkan kesimpulan bahwa Pengaruh perbandingan komposisi dan kecepatan putaran screw pada analisa Kadar Air, Daya Serap Air, Pengembangan Tebal didapatkan kondisi optimum pada kecepatan putaran screw 60 rpm. Namun untuk analisa Kerapatan didapatkan kondisi optimum $20 \mathrm{rpm}$.

\section{DAFTAR PUSTAKA}

[1] D. Maulana, M. DIrhamsyah, D. Setyawati, "Karakteristik Papan Partikel Dari Batang Pandan Mengkuang (Pandanus Atrocarpus Griff) Berdasarkan Ukuran Partikel Dan Konsentrasi Ureaformaldehida," Jurnal Hutan Lestari, vol. 3, no. 2, 2015.

[2] Iskandar, "Proses Pembuatan Papan Partikel, Pusat Penelitian dan Pengembangan Hasil Hutan," 2009.

[3] Setyawati, "Sifat Fisis dan Mekanis Komposit Serbuk Kayu Plastik Polipropilena Daur Ulang,” 2003.

[4] Maradu, "Perancangan unit Extruder Pada Mesin Extrusion Laminasi Fleksible Packaging," J. Tek. Mesin, vol. 2, no. 2, pp. 42-45, 2018.

[5] A. Satito, "Rancang Bangun Mesin Wood Plastic Composite Screw Extrussion Molding," Prosiding Sentrinov, vol. 2, no1. June, pp. 15-16, 2016.

[6] I. Mawardi, "Mutu Papan Partikel dari Kayu Kelapa Sawit Berbasis Perekat Polystrene," J. Tek. Mesin Politek. Negeri Semarang, vol. 11, no. 2, pp. 91-96, 2009. 